\title{
Reducing soil erosion in smallholder farming systems in east Africa through the introduction of different crop types
}

\author{
Tarirai Muoni ${ }^{1,2,3, *}$ (D, Eric Koomson ${ }^{4}$, Ingrid Öborn ${ }^{1,5}$, Carsten Marohn ${ }^{4}$, Christine A. Watson ${ }^{1,3}$, \\ Göran Bergkvist ${ }^{1}$, Andrew Barnes ${ }^{6}$, Georg Cadisch ${ }^{4}$ and Alan Duncan ${ }^{2,7}$ \\ ${ }^{1}$ Crop Production Ecology, Swedish University of Agricultural Sciences, Ulls väg 16, P.O. Box 7043, Uppsala SE-750 07, \\ Sweden, ${ }^{2}$ Feed and Forage Development, International Livestock Research Institute, P.O. Box 30709, Naivasha Road, \\ Nairobi 00100, Kenya, ${ }^{3}$ Crop and Soil Systems, SRUC, Craibstone Estate, Aberdeen AB21 9YA, UK, ${ }^{4}$ Hans Ruthenberg \\ Institute, University of Hohenheim, Garbenstr 13, Stuttgart 70593, Germany, ${ }^{5}$ World Agroforestry (HQ), P.O. Box \\ 30677-00100, United Nations Avenue, Nairobi 00100, Kenya, ${ }^{6}$ Rural Economy, Environment and Society Department, \\ SRUC, West Mains Road, Edinburgh EH9 3JG, UK and ${ }^{7}$ Global Academy of Agriculture and Food Security, The Royal \\ (Dick) School of Veterinary Studies and The Roslin Institute, University of Edinburgh, Easter Bush Campus, Midlothian \\ EH25 9RG, UK
}

${ }^{\star}$ Corresponding author. Email: tarirai.muoni@gmail.com

(Received 27 November 2018; revised 17 July 2019; accepted 23 July 2019; first published online 17 September 2019)

\begin{abstract}
On low-input smallholder farms of Kenyan upland landscapes, erosion of nutrient-rich topsoil strongly affects crop yields. Where maize (Zea mays) is intercropped on erosion-prone slopes, intercropping can potentially reduce soil erosion. The objective of this research was to quantify the contribution of crops and crop mixtures of different growth habits to erosion control and their influence on above-ground biomass and earthworm abundance as indicators of soil function in smallholder farming systems under a bimodal rainfall pattern in Western Kenya. The experiment involved five treatments, namely maize (Z. mays)/common bean (Phaseolus vulgaris) intercrop (maize intercrop), maize/common bean intercrop plus Calliandra (Calliandra calothyrsus) hedgerows and Calliandra mulch (Calliandra), sole Lablab (Lablab purpureus), sole Mucuna (Mucuna pruriens) and groundnut (Arachis hypogaea) intercropped with maize (during the short rains). The experiment was conducted over three consecutive cropping seasons and the cropping system had significant effects on soil loss, runoff, water infiltration, earthworm abundance and above-ground biomass and crop grain yield. The Calliandra treatment had the lowest runoff (11.6-17.2 $\mathrm{mm} \mathrm{ha}^{-1}$ ) and soil erosion (31-446 kg ha ${ }^{-1}$ per season) in all the seasons, followed by the Mucuna treatment. Lablab was affected by disease and showed the highest soil erosion in the last two seasons. Infiltration was highest in Calliandra treatment, and earthworm abundance was higher under Mucuna and Calliandra treatments (229 and 165 earthworms per square metre, respectively) than under other crops. Our results suggest that including sole crops of herbaceous species such as Mucuna, or tree hedgerows with mixtures of maize and grain legumes has the potential to reduce runoff and soil erosion in smallholder farming. Additionally, these species provide a suitable habitat for earthworms which stabilise soil structure and macropores and thus potentially increase infiltration, further reducing soil erosion.
\end{abstract}

Keywords: Calliandra; Infiltration; Intercropping; Legumes; Mucuna; Runoff

\section{Introduction}

Land degradation is a major problem in sub-Saharan Africa (SSA) leading to low agricultural productivity and a need for increased inputs and ultimately leading to land abandonment and loss of

( ) Cambridge University Press 2019. This is an Open Access article, distributed under the terms of the Creative Commons Attribution licence (http://creativecommons.org/licenses/by/4.0/), which permits unrestricted re-use, distribution, and reproduction in any medium, provided the original work is properly cited. 
land for food production (FAO, 2010). It has been estimated that approximately $30 \%$ of land in SSA is degraded due to erosion, nutrient mining, overgrazing and deforestation (Bindraban et al., 2012). Apart from being a threat to food security and human nutrition, surface runoff and soil erosion are major environmental concerns (Fenta et al., 2017). Estimates of crop yield loss caused by erosion in SSA vary but may be substantial on severely eroded soils. For example, maize (Zea mays) yield reductions related to erosion have been estimated at up to 59 and $66 \%$ in Tanzania and Kenya, respectively (Okoba and Sterk, 2010). Yield losses result not only from loss of soil organic matter and nutrients but also from reductions in moisture availability and rooting depth. The rate of erosion from conventionally ploughed land has been estimated to be 1-2 orders of magnitude greater than both rates of erosion under native vegetation and rates of soil formation (Montgomery, 2007) suggesting an urgent need to look for alternative practices that reduce erosion rates. Rates of soil erosion depend on the interaction of several variables (Verheijen et al., 2009), such as erosivity or energy of the eroding agent (wind and water), ground cover and management, slope characteristics and soil properties (erodibility). Control methods for waterinduced erosion, therefore, aim to manipulate both ground cover and soil structure to reduce surface-water flow rates and increase infiltration rates. Methods include covering the soil as much as possible, minimum tillage, contour ploughing, use of grass strips planted on contours, inclusion of shrubs/trees (agroforestry) and use of cover crops (Salako et al., 2006).

In much of east Africa, effective erosion control practices have been poorly implemented (Okoba and Sterk, 2010). Two reasons for poor implementation of erosion control measures in Kenya are lack of evidence of their technical efficiency and social acceptability in different areas (Sigunga and Wandahwa, 2015). Another suggested reason for low uptake of erosion control measures is high initial costs relative to economically beneficial yield gains in the short term (Nyangena and Köhlin, 2008). One method of erosion control, which does not require large investments, is increasing crop diversity potentially through utilising species mixtures within a single growing season and in increasing diversity within crop rotations. Legume species (herbaceous, grain and tree legumes) are among candidates for increasing crop diversity due to their high nutritional value as food and fodder and their ability to biologically fix nitrogen. Herbaceous legumes are plants with non-woody stems above ground (Mongkhonsin et al., 2019) and in this paper, we refer to them as crops mainly used as cover crops and/or fodder crops. Farmers in east Africa generally practice intercropping, for example, maize (Z. mays) and common bean (Phaseolus vulgaris), which increases soil cover and improves resource use efficiency compared to sole cropped maize (Himmelstein et al., 2017). Herbaceous and tree legumes may also be used in cropping systems to reduce soil erosion while also providing other products and services. They have the potential to contribute to soil erosion control because they have fast growth rates, high biomass production and some of them are drought-tolerant (Kaspar et al., 2011). Rapid growth rates provide ground cover that helps reduce the impact of raindrops and direct sunlight hence improving soil and water conservation (Kaspar et al., 2011). High biomass productivity also increases soil organic matter content which improves soil structure as well as earthworm density, which contributes to water infiltration and holding capacity (Jordán et al., 2010). Additionally, legumes provide a series of other functions potentially useful to smallholder farmers including provision of food, livestock feed, income and soil fertility improvement through biological nitrogen fixation (BNF) and addition of organic matter. Tree legumes also have other purposes within smallholder farms including providing a source of fuel or construction material. Different legume types can be incorporated into smallholder farming systems through intercropping, in crop rotations, and planted on farm boundaries and as hedgerows. Livestock is important in east Africa and contributes $20-30 \%$ of national gross domestic product; hence, they play a significant role in farming livelihoods (EAFF, 2012). The use of herbaceous legume species such as Mucuna (Mucuna pruriens) and Lablab (Lablab purpureus) and grain legumes such as cowpea (Vigna unguiculata) and groundnut (Arachis hypogaea) could thus play a useful role in providing fodder, as well as improving and protecting the soil. 


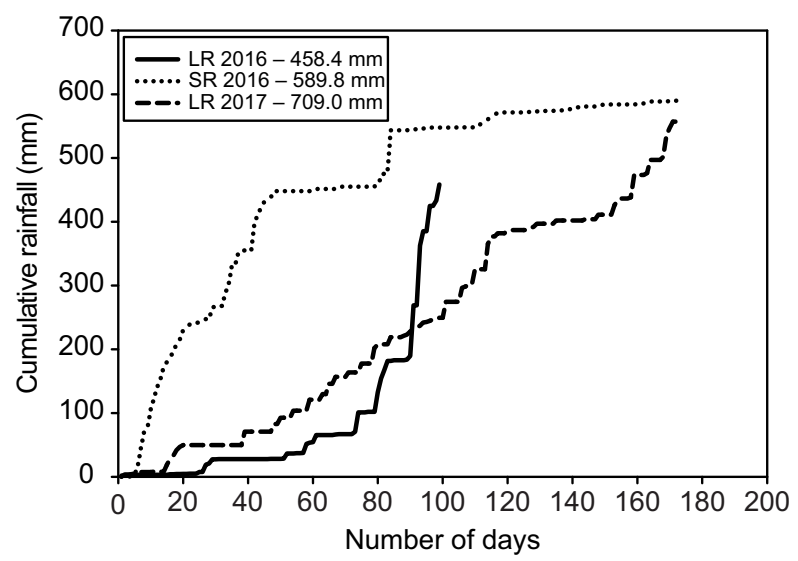

Figure 1. Cumulative rainfall for all cropping seasons. LR $2016 x$-axis is in days after planting (25 May 2016), for SR 2016 (planted 8 September 2016) and LR 2017 (planted 1 March 2017) is in days after the first day of the month when season starts.

Table 1. Soil properties at the experimental site in Rongo district, Migori County, Western Kenya

\begin{tabular}{lcccccccccc}
\hline Depth $(\mathrm{cm})$ & $\mathrm{pH}$ & Org C (\%) & Total N (\%) & $\mathrm{C} / \mathrm{N}$ ratio & $\begin{array}{c}\mathrm{BD} \\
\left(\mathrm{g} \mathrm{cm}^{-3}\right)\end{array}$ & $\begin{array}{c}\text { Avail P } \\
\left(\mathrm{mg} \mathrm{kg}^{-1}\right)\end{array}$ & $\begin{array}{c}\text { Avail K } \\
\left(\mathrm{mg} \mathrm{kg}^{-1}\right)\end{array}$ & Sand (\%) & Silt (\%) & Clay (\%) \\
\hline $0-20$ & 4.8 & 1.0 & 0.1 & 9.9 & 1.3 & 0.9 & 61.0 & 63 & 12 & 25 \\
$20-40$ & 4.9 & 0.9 & 0.1 & 10.0 & 1.4 & 0.1 & 77.0 & 56 & 13 & 31 \\
\hline
\end{tabular}

$\mathrm{pH}$ (measured in $0.01 \mathrm{M} \mathrm{CaCl}_{2}$ extraction with soil to extraction solution ratio of 1:2.5); $\operatorname{Org} \mathrm{C}=$ organic carbon, $\mathrm{N}=$ nitrogen, $\mathrm{BD}=$ bulk density, available phosphorus (P) and potassium (K). Available P was determined by Bray 1 with Beckman coulter Du, UV - Du 640 spectrophotometers, USA. Available K was analysed by Calcium-Acetate-Lactate-extraction method.

There is little research that has focused on the ability of different legume types to contribute to the control of soil erosion in smallholder farming systems in east Africa. Thus, the main objective of this study was to assess the efficiency of integration of different crop types (represented by herbaceous, grain or woody legumes) in preventing surface runoff and soil erosion compared to maize-common bean intercropping that represents the typical cropping system in the region. Soil erosion measurements using runoff plots have been successfully used in several recent papers and that method was applied in this study (e.g. Thierfelder and Wall, 2009). We also assessed the effect of different crop types and crop mixtures (with legumes) on water infiltration and earthworm abundance as indicators of soil function, and total above-ground biomass produced. The hypotheses tested were (i) the introduction of herbaceous or woody species can reduce soil erosion compared to maize-common bean intercropping and (ii) herbaceous species and mulching enhance water infiltration and earthworm populations compared to annual grain legumes intercropped with maize.

\section{Materials and Methods}

\section{Site description}

The experiment was conducted on farm in Rongo district, Migori County $\left(00^{\circ} 77^{\prime} \mathrm{S}, 34^{\circ} 60^{\prime} \mathrm{E} ; 1474 \mathrm{~m}\right.$ above sea level), in Western Kenya. The area is characterised by a sub-humid climate and receives rainfall in a bimodal pattern, with approximately $1000 \mathrm{~mm}$ per annum (Figure 1). In general, the rainy seasons last from March to July (long rain [LR]) and from September to December (short rain [SR]). Annual average temperature is about $20^{\circ} \mathrm{C}$. Predominant soils are Acrisols according to FAO classification and the land is generally sloping. The soil at the experimental site is a sandy clay loam (Table 1) and the slope is around $20 \%$. Common crops in the region include maize (Z. mays L.), sugarcane 
(Saccharum officinarum), tea (Camellia sinensis), coffee (Coffea arabica), banana (Musa L.), groundnut and common bean (Rapsomanikis, 2015). The main livestock species are cattle, goats, sheep and chickens. Farmers utilise both cropping seasons and generally prefer to intercrop maize and common bean for food security and efficient land utilisation, and the average farm size is approximately 2 ha (Rapsomanikis, 2015). Land preparation and weed management are usually done with ox-drawn mouldboard plough or hand hoes (Rapsomanikis, 2015). The study farm had been cultivated for more than 10 years with mainly cassava, maize, common bean and groundnuts.

\section{Experimental design}

The experiment was established early in 2016 during the long rain (LR 2016) season and was continued during the subsequent 2016 short rain (SR 2016) and long rain (LR 2017) cropping seasons. It was arranged according to a randomised complete block design with five treatments and three replicates.

The treatments were as follows: maize/common bean intercrop (maize intercrop); groundnut as sole crop during LR and intercropped with maize during SR (groundnut) (following farmer practice); Lablab (L. purpureus) as a sole crop (Lablab); Mucuna (M. pruriens) as a sole crop (Mucuna) and maize/common bean intercrop plus Calliandra calothyrsus hedgerow and leaf mulch (Calliandra).

Soil samples were collected with a soil auger (internal diameters $7 \mathrm{~cm}$ ) at two depths $(0-20 \mathrm{~cm}$ and $20-40 \mathrm{~cm}$ ) just before planting in April 2016. Ten soil samples from each depth were bulked to give one sample per block, and sub-samples of $500 \mathrm{~g}$ were saved for further analysis. Soil $\mathrm{pH}$ was determined in 1:2.5 soil and 0.01 $\mathrm{M} \mathrm{CaCl}_{2}$ suspension using a Labor-pH-meter (WTW GmbH, Germany). Total $\mathrm{N}$ and $\mathrm{C}$ were analysed using dry combustion (Flash EA 1112 Elemental Analyser, Germany). Soil texture was determined using the pipette method, after having removed the organic matter using 35\% hydrogen peroxide. Available K was extracted using CalciumAcetate-Lactate solution and measured by Inductively Coupled Plasma Optical Emission Spectrometry (Agilent 5100 ICP-OES, Germany). Available P was extracted using Bray No 1 extractant and analysed on spectrophotometer (Beckman UV/Vis Spectrophotometer DU ${ }^{\circledR}$ 640, Germany). For bulk density determination, $110 \mathrm{~cm}^{3}$ undisturbed cylinder cores were taken, the soil oven-dried at $105{ }^{\circ} \mathrm{C}$, and the bulk density was calculated using the volume of the core.

The crops were sown after the first effective rains in all seasons, except for the LR 2016 season when crops were established a bit later. Establishment was delayed by a long dry spell after the runoff plot structures were constructed (at the beginning of the rainy season). Land was prepared using an ox-drawn mouldboard plough to a depth of approximately $20 \mathrm{~cm}$, at the onset of the experiment to remove Cynodon nlemfuensis Vanderyst (African Bermuda-grass) which was common on the site and to loosen the soil for improved seed establishment. In the following seasons (September 2016 SR and March 2017 LR), land preparation was carried out with hand hoes (tilling depth approximately $20 \mathrm{~cm}$ ) 2 weeks after harvesting the preceding crops. From the SR 2016 cropping season, $50 \%$ of the harvested leaf and stem biomass in all treatments was retained in the respective plots and was uniformly spread soon after sowing the following crop, following recommendations from Mupangwa and Thierfelder (2014) and allowing the remaining crop residues to be used for feeding livestock or other purposes. Each main plot measured $12 \mathrm{~m} \times 6 \mathrm{~m}\left(72 \mathrm{~m}^{2}\right)$ and consisted of a bounded runoff plot measuring $12 \mathrm{~m} \times 4 \mathrm{~m}\left(48 \mathrm{~m}^{2}\right)$ in the centre with a $1 \mathrm{~m}$ buffer zone on both sides of the aluminium sheets (Muoni et al., 2018). At the start of the experiment, aluminium sheet boundaries were buried $0.20 \mathrm{~m}$ into the soil around the runoff plots to prevent water flow from adjacent plots or outside of the experimental area. At the bottom of each runoff plot, a triangular cross-section was constructed with a $5-\mathrm{cm}$ diameter iron pipe outlet connected to two 100-L tanks to collect runoff and soil sediments. The first tank had six equidistant levelled splitter outlets. One splitter outlet was then connected to a second tank (splitter tank), to account for the overflowing water from the splitter on the first tank. 
All crops and the Calliandra hedgerows were planted across the slope. Maize was sown at $0.75 \mathrm{~m} \times 0.30 \mathrm{~m}$ to achieve 44444 plants $\mathrm{ha}^{-1}$. Common bean was sown in between the maize rows, spaced at $0.20 \mathrm{~m}$ between plants giving 66666 plants ha $^{-1}$. Mucuna and Lablab were sown at $0.50 \mathrm{~m}$ between rows and $0.20 \mathrm{~m}$ between plants $\left(100000\right.$ plants $\left.\mathrm{ha}^{-1}\right)$. Sole groundnut was spaced $0.45 \mathrm{~m} \times 0.15 \mathrm{~m}$ to achieve 148148 plants $\mathrm{ha}^{-1}$, for intercropping they were sown between the maize rows at the same in-row spacing (74 074 plants ha ${ }^{-1}$ ). Fertiliser applications in all crops followed the recommended application rates in the region. All maize plots received $100 \mathrm{~kg} \mathrm{ha}^{-1}$ of diammonium phosphate (DAP) $\left(18 \mathrm{~kg} \mathrm{~N}: 46 \mathrm{~kg} \mathrm{P}_{2} \mathrm{O}_{5}(20 \mathrm{~kg} \mathrm{P}) \mathrm{ha}^{-1}\right)$ fertiliser at sowing. Sole legumes received $45 \mathrm{~kg}$ $\mathrm{ha}^{-1}$ of DAP ( $\left.8 \mathrm{~kg} \mathrm{~N}: 21 \mathrm{~kg} \mathrm{P}_{2} \mathrm{O}_{5}(9 \mathrm{~kg} \mathrm{P}) \mathrm{ha}^{-1}\right)$. Thus, intercrops received $145 \mathrm{~kg} \mathrm{ha}^{-1}$ DAP. Reseeding in places of poor germination ('gap filling') was done approximately 2 weeks after initial sowing. All maize crops were top dressed, at 4 and 7 weeks after sowing in two equal splits, using calcium ammonium nitrate fertiliser $\left(26 \mathrm{~kg} \mathrm{~N} \mathrm{ha}^{-1}\right)$. Hand weeding was carried out at least twice in each cropping season, and the first and second weeding was carried out at 4 and 7 weeks after sowing in each season followed by a third weeding when deemed necessary. Aphids and leaf-eating caterpillars were controlled using Karate (active ingredient (a.i) Lambda-cyhalothrin), and fungal diseases on legumes were controlled using Redomil (a.i. metalaxyl-M plus mancozeb) at recommended application rates.

The Calliandra hedgerows were established using small seedlings spaced at $4 \mathrm{~m} \times 0.50 \mathrm{~m}$ (19 August 2016) in the beginning of the SR 2016 cropping season (seedlings were not available in LR 2016). Each plot had three hedgerows that were placed at the top, middle and bottom of the plot. The seedlings received supplementary watering for the first 3 weeks to prevent wilting. The seedlings grew naturally until the end of the LR 2017 when they were cut at $0.60 \mathrm{~m}$ height. Calliandra mulch was imported from the nearby farms in the LR 2016 before the hedgerows were established, and also in the following seasons because the seedlings in the plots were too small to provide sufficient quantities of plant material. The mulch was applied at $5 \mathrm{Mg} \mathrm{ha}^{-1}$ soon after sowing in all seasons.

\section{Field measurements}

\section{Runoff and soil erosion}

Runoff and soil erosion measurements were carried out after each rainfall event that resulted in accumulation of water in the tanks. The second tank accounted for $1 / 6$ of the overflow from first tank. The total overflow was then added to the volume of water in the first tank. The total volume from all the rain events was added and converted to give runoff in cubic metre per hectare.

All soil sediments collected from each tank were weighed on each sampling occasion. Thoroughly mixed soil sediments sub-samples weighing approximately $500 \mathrm{~g}$ were collected from both tanks for oven-drying. In cases where the soil sediments collected were below $500 \mathrm{~g}$, the whole sample was used. Soil sediments sub-samples were oven-dried at $105^{\circ} \mathrm{C}$ until a constant weight was reached. The quantity of soil sediments from the splitter tank was also multiplied by six as in the case of runoff. Soil erosion is reported on a dry weight basis in kilogram per hectare.

\section{Water infiltration}

Infiltration measurements were carried out during the SR 2016 and LR 2017. Water infiltration was measured on 14 November 2016 (67 days after planting) and 5 May 2017 (65 days after planting) during the SR and LR, respectively, using a single ring infiltrometer measuring $5.08 \mathrm{~cm}$ in diameter and $12.70 \mathrm{~cm}$ in depth. The ring was driven $5 \mathrm{~cm}$ into the soil in an area cleared of plant material. The infiltration was measured by pouring $107 \mathrm{~mL}$ of water into the ring and recording the time taken for the water to infiltrate the soil. The procedure was repeated at three random positions in each plot. 


\section{Earthworms}

Sampling of earthworms was carried out at three sampling points in each plot on two occasions, in November 2016 (SR 2016) and May 2017 (LR 2017), that is, approximately 60 days after sowing when there was adequate soil moisture. The sampling was done in the buffer zone outside the main runoff plot to avoid soil disturbance that may have affected soil loss results. A metal frame measuring $0.25 \mathrm{~m} \times 0.25 \mathrm{~m}$ was randomly placed in the plot and all crop residues in the area were removed. The soil was extracted to a depth of $10 \mathrm{~cm}$ and hand sorted for earthworms. Both earthworms and soil were returned to the sampling point after counting the earthworms.

\section{Above-ground biomass and crop grain yield}

Biomass data were collected from eight central rows, each crop measuring $3 \mathrm{~m}$ long. The total fresh weight of biomass from the net plot was weighed and a sub-sample (500 g) was oven-dried at $80{ }^{\circ} \mathrm{C}$ for 48 hours. The sub-sample dry weight and fresh weight ratio was used to determine biomass dry weight in kilogram per hectare. All three Calliandra hedgerows were pruned during the LR 2017 season at $0.60 \mathrm{~m}$ from soil surface in each plot, and the leaves and stems in each plot were weighed separately. The average weight of leaves and stems in the three rows was calculated to give fresh weights of each plot. Stem and leaf sub-samples of approximately $200 \mathrm{~g}$ were collected at each weighing. The sub-samples were oven-dried at $80{ }^{\circ} \mathrm{C}$ for 48 hours. In intercropping treatments, total biomass included all harvested crop material including Calliandra in the appropriate treatment.

The maize grain yield was harvested on eight central rows, each measuring $3 \mathrm{~m}$. The fresh weight of all cobs in the eight rows was measured immediately after harvesting, and a sub-sample of 10 randomly selected cobs was taken for air-drying. The fresh and air-dry weights of the subsamples were measured, and grain yield was calculated at the recommended $12 \%$ moisture content. For common bean and groundnut intercropped with maize, the crops were harvested between eight central maize rows, each measuring $3 \mathrm{~m}$. Total fresh weight of the pods was measured in the field and a pod sub-sample of approximately $500 \mathrm{~g}$ was collected for air-drying. The grain yield for legumes was calculated at $9 \%$ moisture basis. Sole Mucuna and Lablab grain data were collected using the same procedure as for common bean and groundnuts.

\section{Statistical analysis}

All data collected were subjected to heterogeneity of variance and normality tests and then the analysis of variance was carried out, using Statistix 9 statistical package for personal computers, to assess the treatment effects on soil loss, runoff, water infiltration, earthworm populations, and total above-ground biomass and grain yield (both maize and legumes) produced. The means of the three sampling points for earthworms and infiltration per plot were used in statistical analysis. Mean separation was carried out using the least significance difference test at $p \leq 0.05$ on all significant data.

\section{Results}

\section{Runoff, soil erosion and water infiltration}

Cropping season had a significant effect on runoff. Runoff was higher during the LR 2017 and SR 2016 seasons than in the LR 2016 season (Figure 2). Also, runoff differed significantly between crop treatments in all three cropping seasons (Figure 2). The treatment Calliandra showed the lowest runoff in all seasons. Mucuna was the second most efficient crop in reducing surface runoff across the seasons, while the effects of the other crops were inconsistent. During the LR 2016 cropping season, runoff from the groundnut treatment was as low as from the Calliandra treatment, whereas in SR 2016 and LR 2017, runoff under groundnuts was as high as with the worst 


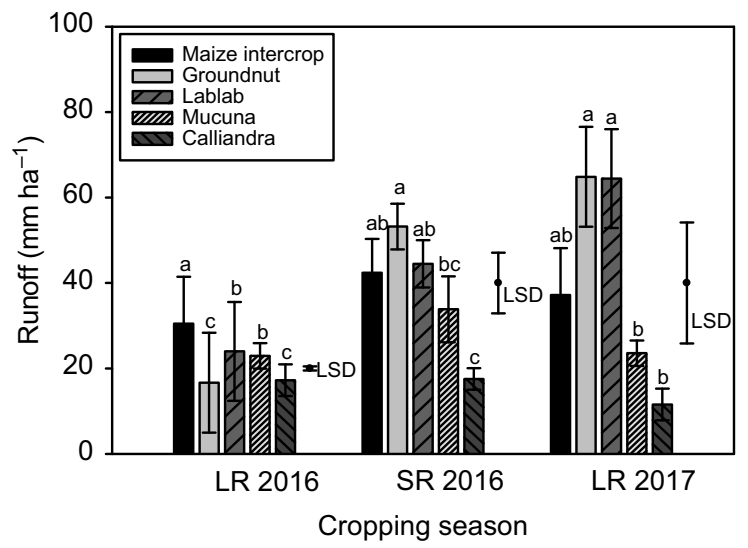

Figure 2. Effect of treatments on runoff during the 2016 long rains (LR 2016) and short rains (SR 2016), and the LR 2017 in Rongo district, Migori County, Western Kenya. Groundnut was intercropped with maize during the SR 2016 season. Means with different letters in the same cropping season are significantly different from each other. Error bars are standard error of mean. LSD = least significant differences.

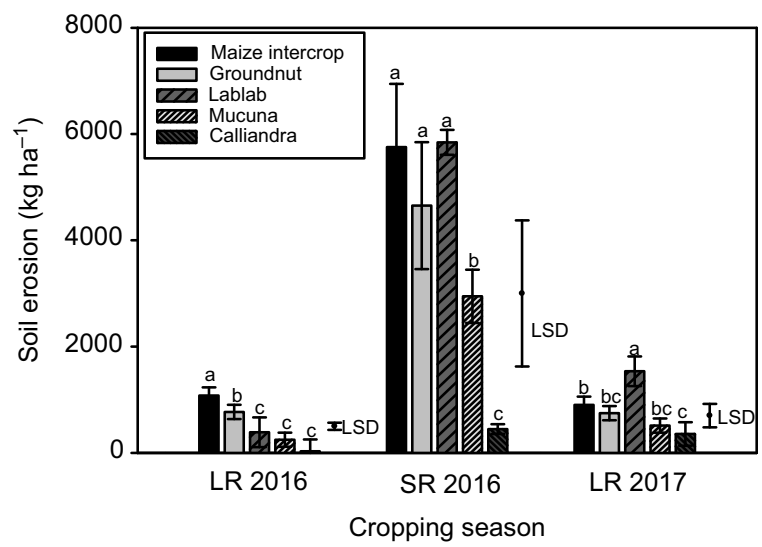

Figure 3. Effect of treatments on soil loss during the LR 2016, SR 2016 and LR 2017 cropping seasons. Groundnut was intercropped with maize during the SR 2016 season. Means with different letters in the same cropping season are significantly different from each other. Error bars are standard error of mean. LSD = least significant differences.

performing crops. In the LR 2016, Lablab and Mucuna treatments had similar and intermediate runoff, whereas during the SR 2016 and LR 2017, Lablab was diseased and did not differ significantly from the maize-common bean (control) and the groundnut treatments. Both LR seasons had an extended mid-season dry spell when compared to the SR season (Figure 1).

Soil erosion differed by cropping season with SR 2016 having more soil erosion than LR 2016 and LR 2017 (Figure 3). Soil erosion was also affected by treatments during the three cropping seasons investigated in this study (Figure 3). Soil erosion was lowest on the Calliandra treatment in all three seasons, and the Mucuna treatment was similarly low during the first and the last seasons $(<500 \mathrm{~kg}$ $\mathrm{ha}^{-1}$ ). During the LR 2016, Lablab, Mucuna and Calliandra caused similar and lowest soil erosion, while the maize intercrop led to the highest erosion. Overall, there was much greater soil erosion in all treatments during SR 2016 (up to $6000 \mathrm{~kg} \mathrm{ha}^{-1}$ ) as compared to LR 2016 and LR 2017, except for Calliandra where erosion remained low. In the SR 2016 season, maize intercrop, groundnut and Lablab had the highest soil loss, Mucuna caused intermediate and Calliandra caused the lowest. During 
Table 2. Effect of treatments on infiltration in Rongo during the short rains in 2016 and long rains in 2017

\begin{tabular}{|c|c|c|}
\hline \multirow[b]{3}{*}{ Treatments } & \multirow{2}{*}{$\frac{\text { Short rains } 2016}{\text { Infiltration }}$} & \multirow{2}{*}{$\frac{\text { Long rains } 2017}{\text { Infiltration }}$} \\
\hline & & \\
\hline & $\left(\mathrm{mL}\right.$ second $\left.^{-1}\right)$ & $\left(\mathrm{mL}\right.$ second $\left.^{-1}\right)$ \\
\hline Maize/Common bean intercrop & $2.7^{\mathrm{b}}$ & 1.9 \\
\hline Groundnut $^{*}$ & $3.0^{\mathrm{b}}$ & 2.0 \\
\hline Lablab & $2.2^{\mathrm{b}}$ & 1.3 \\
\hline Mucuna & $5.0^{\mathrm{a}}$ & 1.4 \\
\hline Calliandra & $5.6^{\mathrm{a}}$ & 2.6 \\
\hline Least significant differences (LSD) & 1.55 & NS \\
\hline$p$-value & 0.003 & NS \\
\hline
\end{tabular}

*Groundnut was intercropped with maize during the SR 2016 season. Means with different letters are significantly different from each other.

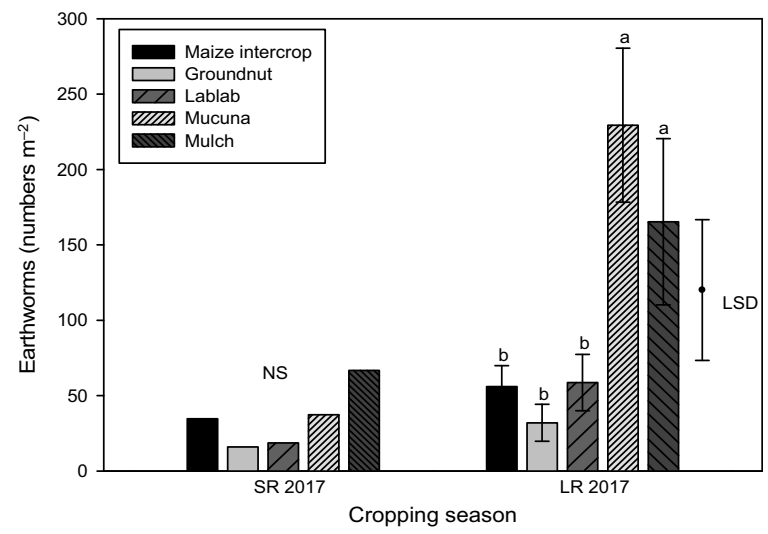

Figure 4. Effect of treatments on earthworm population during the 2016 short rains (SR 2016) and 2017 long rains (LR 2017) cropping seasons in Rongo. Groundnut was intercropped with maize during the SR 2016 season. Means with different letters in the same cropping season are significantly different from each other. Error bars are standard error of mean. LSD $=$ least significant differences.

the LR 2017 season, soil erosion was relatively low overall (500-1500 $\mathrm{kg} \mathrm{ha}^{-1}$ ) and similar to LR 2016. Soil erosion was highest under Lablab followed by maize intercrop. Calliandra, Mucuna and groundnut showed the lowest soil loss.

Treatments had a significant effect on water infiltration during the SR 2016 only (Table 2). The highest water infiltration was observed under Calliandra and Mucuna treatments, while the lowest was observed in Lablab treatment. Calliandra caused $154 \%$ higher infiltration rate than Lablab and $107 \%$ higher than the maize intercrop treatment.

\section{Earthworm population}

The treatments had a significant effect on earthworm populations during the LR 2017 season only (Figure 4). Mucuna and Calliandra caused similar, large earthworm populations compared to other treatments. The earthworm populations tended to be larger in Calliandra than in the other treatments also in SR $2016(p=0.28)$. Treatments with low earthworm populations had high surface runoff (Figure 5a) and soil loss (Figure 5b) during the SR 2016 and LR 2017 cropping seasons. 
(a)
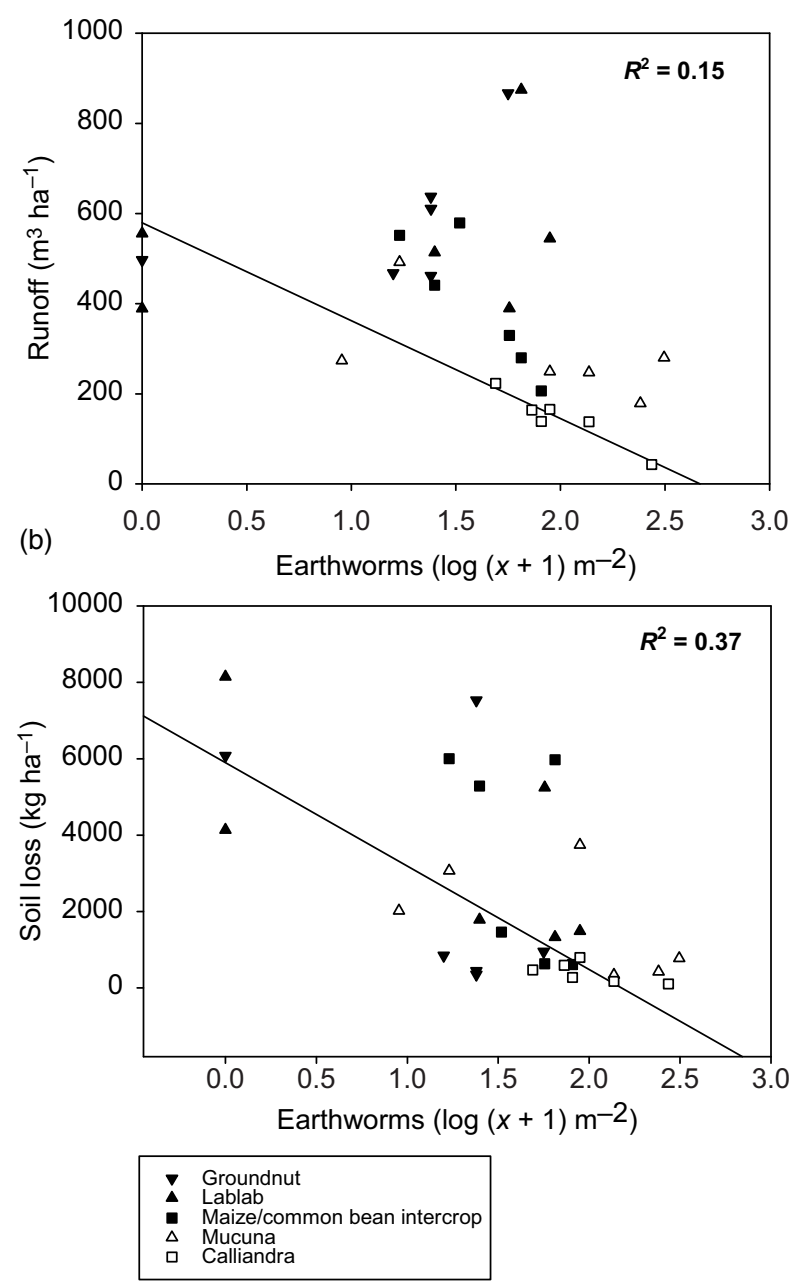

Figure 5. Effect of earthworms in different treatments on (a) runoff and (b) soil loss during the SR 2016 and LR 2017 season. Significance of the correlations was not tested because the data points in the regression were not independent. $x$ - earthworms per square metre.

\section{Above-ground biomass and crop grain yield}

The total biomass produced was larger and more affected by treatment in the SR 2016 season than in the LR 2016 (Table 3). In the SR 2016 season, the highest biomass was observed in groundnut/maize intercrop, Mucuna and Calliandra treatments, while Lablab produced the smallest biomass. In the LR 2017 season, Calliandra produced the largest total biomass followed by maize intercrop.

Treatment had a significant effect on maize and legume grain yields during the SR 2016, where Calliandra treatment was larger than maize intercrop and groundnut treatments. Mucuna treatment produced a higher grain yield than other legume treatments (Table 3). During the LR 2017 season, treatments had a significant effect on legume grain yields only and the same trend was observed when Mucuna had the largest yield (Table 3). LR 2017 season had higher crop yields than SR 2016 in all treatments except for Lablab. 
Table 3. Crop grain and above-ground biomass yield $\left(\mathrm{kg} \mathrm{ha}^{-1}\right)$ in Rongo during the short rains in 2016 and long rains in 2017

\begin{tabular}{|c|c|c|c|c|c|c|}
\hline \multirow[b]{2}{*}{ Treatments } & \multirow[b]{2}{*}{ Crops } & SR 2016 & LR 2017 & LR 2016 & SR 2016 & LR 2017 \\
\hline & & \multicolumn{2}{|c|}{ Grain yield $\left(\mathrm{kg} \mathrm{ha}^{-1}\right)$} & \multicolumn{3}{|c|}{ Above-ground biomass yield $\left(\mathrm{kg} \mathrm{ha}^{-1}\right)$} \\
\hline \multirow[t]{2}{*}{ Maize intercrop } & Common bean & $79^{b}$ & $229^{b}$ & 3192 & $4336^{\mathrm{B}}$ & $8532^{\mathrm{A}}$ \\
\hline & Maize & $3071^{B}$ & 7260 & & & \\
\hline \multirow[t]{2}{*}{ Groundnut } & Groundnut & $73^{b}$ & $418^{\mathrm{b}}$ & 2411 & $6592^{A}$ & $3040^{\mathrm{B}}$ \\
\hline & Maize & $3361^{\mathrm{B}}$ & - & & & \\
\hline Lablab & Lablab & $209^{b}$ & $80^{\mathrm{b}}$ & 2318 & $548^{\mathrm{C}}$ & $176^{\mathrm{C}}$ \\
\hline Mucuna & Mucuna & $1626^{a}$ & $3433^{a}$ & 2963 & $6197^{A B}$ & $5097^{\mathrm{B}}$ \\
\hline \multirow[t]{2}{*}{ Calliandra } & Common bean & $108^{b}$ & $240^{\mathrm{b}}$ & 3481 & $5257^{A B}$ & $10426^{A}$ \\
\hline & Maize & $4339^{A}$ & 4697 & & & \\
\hline
\end{tabular}

LR 2016 has no grain yield data due to poor crops/crops not reaching maturity. Groundnut was intercropped with maize during the SR 2016 season and grown as sole crop LR 2017 (following farmer practice).

Statistical significances are indicated with different letters $(p<0.05)$ for maize ${ }^{(A, B)}$ and legume $e^{(a, b)}$ grain yield. Above-ground biomass yield is the total biomass of the treatment.

\section{Discussion}

Soil erosion control is a critical issue in smallholder farming systems in SSA. The washing away of organic matter and nutrient-rich topsoil, accompanied by low fertiliser use, results in low crop yields. The use of intercrops including different types of legumes has the potential to improve soil fertility through reduction of soil erosion and addition of nitrogen through BNF.

\section{Runoff, soil erosion, water infiltration and abundance of earthworms}

Mucuna and Calliandra caused low soil erosion and runoff during the study period. Although the first season trial was established late, this did not affect the results since the same trend of less soil erosion was observed from Calliandra and Mucuna treatments as from other treatments throughout the study period. Soil erosion observed during LR seasons in this study was generally low when compared to other studies, for example, $6.9 \mathrm{Mg} \mathrm{ha}^{-1}$ recorded under no-till plus legume intercrop in Zimbabwe 2005/06 cropping season (Thierfelder and Wall, 2009), $>2 \mathrm{Mg} \mathrm{ha}^{-1}$ under different crop and tillage management in Western Kenya (Ampofu et al., 2002) and $52 \mathrm{Mg} \mathrm{ha}^{-1}$ year $^{-1}$ on bare soils during 2010/11 cropping season in Southern Africa (Paterson et al., 2013). Since the general level of erosion was small compared to other experiments conducted under similar conditions, the relatively small differences found in the present experiment can be expected to be of greater importance in situations as in the work referred to. Thus, the experiment supported the hypothesis that herbaceous and woody species can reduce soil erosion compared to maizecommon bean intercropping. Increased infiltration was observed under Mucuna and Calliandra treatments, which also supports the hypothesis that herbaceous legumes and tree legumes with mulching enhance water infiltration and earthworm populations compared to intercropping of annual crops and sole grain legumes.

Soil erosion, runoff and infiltration were probably reduced by the high soil cover provided by the crop canopies and residues (Montgomery, 2007; Thierfelder and Wall, 2009). Retention of crop residues increased soil cover at the onset of the season before crop establishment, which reduced raindrop impact, soil erosion and runoff. Raindrop energy loosens and displaces soil particles and this energy is dissipated by ground cover (Kaspar et al., 2011). Living and non-living mulch also diminishes the velocity of runoff which reduces the dispersion of soil particles from their original source thus reducing erosion (Kaspar et al., 2011). Mulching also increases surface roughness and thus reduces runoff velocity and increases ponding, giving the opportunity for increased water infiltration (Jordán et al., 2010). The greater above-ground biomass production in treatments with Mucuna and Calliandra also increases litter and organic material in the soil, which 
improves aggregation of soil particles. The addition of mulch favoured earthworm population build-up, and the Calliandra leaves dropping during the season increased litter which may have improved moisture retention and feed availability for earthworms (Buchholz et al., 2017). More soil cover protects soil from direct sunlight and thus evaporation of surface water. This improves the retention of soil moisture, which is important for earthworm survival (Ivask et al., 2006). Both mulching and earthworm build-up contribute to more water infiltration (Jordán et al., 2010). As the Calliandra hedgerows grew, they provided additional ground cover which helped reduce runoff and soil loss. This could be the effect of changes in microtopography of the hedgerows (Lin et al., 2009) and earlier development of leaves at the beginning of the season, when the existing shrub roots can make use of residual soil moisture.

Establishing and pruning legume hedgerows for high quantities of fodder (or mulch) is labour intensive. Although tree and herbaceous legumes are valuable feed sources for animals and have been shown to increase milk production (Paterson et al., 2013), farmers are less willing to incorporate them because they lack experience in growing these crops. There is a very low interest in herbaceous legumes since farmers prefer growing grain legumes to provide food security for their families (Muoni et al., 2019). One way to increase interest in the inclusion of herbaceous or tree legumes would be to stress its usefulness as fodder in addition to the soil fertility enhancing and soil conservation aspects, but adoption is more likely in cases where livestock play an important role in income generation.

The maize intercrop had higher runoff and soil erosion than the other treatments during the LR 2016 cropping season, probably due to the long dry spell. Due to late establishment in that season, both maize and common bean suffered during the long dry spell and the vegetative growth period and thus produced little ground cover that could prevent runoff and soil erosion. Maize and common bean were more affected by moisture stress than Mucuna, Lablab and groundnut. More soil erosion and runoff were observed when the sole crop was in poor health, as we observed with Lablab in the seasons with pest issues. In such situations, crop mixtures will generally perform better than sole crops, because it is less likely that two or more crops will fail simultaneously, and the additional crop helps maintain ground cover (Rapsomanikis, 2015). In addition, crops such as Mucuna, Lablab and groundnut are all relatively drought-tolerant and can provide ground cover even under harsh conditions.

\section{Above-ground biomass and crop grain yield}

Crop biomass is crucial in smallholder farms for livestock feed, soil improvement, fuel and construction. Incorporating different crop types, for example, legumes in smallholder farms helps provide soil cover and livestock feed of better quality that helps improve soil fertility and livestock productivity. Groundnut intercropped with maize produced the largest biomass in SR 2016 season, while Calliandra (with maize and common beans) produced the largest biomass in LR 2017 season. Although the Calliandra treatment produced high biomass, farmers need to be aware of the potential yield penalty resulting from competition for water, nutrients, light and space between crops and hedgerows, which can be reduced by regular pruning of hedgerows (De Costa and Surenthran, 2005). Biomass during the LR 2016 was lower than during other seasons because of late planting, and a long dry spell during the vegetative growth stage. When crop residues remain in the field, soil organic matter can increase (Jordán et al., 2010) and this can increase biological activity and soil aggregate formation. Thus, legume crops that produce high biomass enable dual benefits of livestock feed and soil improvement, which improve farm productivity.

The maize intercrops produced high grain yields that may help farmers remain food secure. The Calliandra treatment had the largest maize yield during SR 2016 season due to the additional organic matter that was added by leaf mulch from the previous season. However, the Calliandra treatment had lower maize yield in the final season than maize intercrop treatment which may have been due to increased competition with Calliandra hedgerows and subsequent yield loss 
(De Costa and Surenthran, 2005). Competitive crops such as Mucuna may be rotated with maize, which can help control soil erosion, improve soil fertility, provide livestock feed and provide food for farmers (Bonsu and Asibuo, 2013).

\section{Conclusions}

Incorporating a mixture of crop types in cropping systems has the potential to reduce runoff and soil loss and increase earthworm populations and infiltration in smallholder farms. Based on the results from this study, we conclude the following: use of a mixture of crop types including herbaceous and woody species in cropping systems increases soil cover, which reduces the impact of raindrops, as well as runoff and soil erosion. High soil cover can be attained in various ways including intercropping (e.g. establishing Calliandra hedgerows in maize/common bean intercrop) or crop rotations with herbaceous legumes that produce large amounts of biomass (e.g. Mucuna). By including a mixture of crop types, water infiltration can be improved through increased soil cover and soil organic matter. Mucuna and Calliandra treatments produced both high soil cover and above-ground biomass than treatments with only grain crops, which resulted in high infiltration rates and numbers of earthworms. Large earthworm populations contribute to increase water infiltration through soil aggregate formation and increased porosity. Inclusion of legume crops with high biomass production allows farmers to use some biomass for protein-rich livestock feed in integrated crop-livestock systems while improving soil fertility.

Acknowledgements. We wish to acknowledge the German Academic Exchange Scheme (DAAD), Scotland's Rural College (SRUC) and SLU for funding this research. We are also grateful to the KALRO Kisii Centre in Kenya for logistical support throughout the research period. We would like to thank Johannes Forkman for his advice on statistical analysis, Samuel Obuche for supporting the conduct of this work on his farm, and Marcos Lana and Petra Gwaka for comments on the manuscript. We also thank the anonymous reviewer for constructive comments.

\section{References}

Ampofu E.A., Muni R.K. and Bonsu M. (2002). Estimation of soil losses within plots as affected by different agricultural land management. Hydrological Sciences Journal 47, 957-967. https://doi.org/10.1080/02626660209493003

Bindraban P.S., van der Velde M., Ye L., van den Berg M., Materechera S., Kiba D.I., Tamene L., Ragnarsdóttir K.V., Jongschaap R., Hoogmoed M., Hoogmoed W., van Beek C. and van Lynden G. (2012). Assessing the impact of soil degradation on food production. Terrestrial Systems 4(5), 478-488.

Bonsu P.O. and Asibuo J.Y. (2013). Rotational effects of legumes on maize yield. International Journal of Scientific \& Technology Research 2, 222-227.

Buchholz J., Querner P., Paredes D., Bauer T., Strauss P., Guernion M., Scimia J., Cluzeau D., Burel F., Kratschmer S., Winter S., Potthoff M. and Zaller J.G. (2017). Soil biota in vineyards are more influenced by plants and soil quality than by tillage intensity or the surrounding landscape. Scientific Reports 7. https://doi.org/10.1038/s41598-017-17601-w

De Costa W.A.J.M. and Surenthran P. (2005). Tree-crop interactions in hedgerow intercropping with different tree species and tea in Sri Lanka: 1. Production and resource competition. Agroforestry Systems 63, 199-209. https://doi.org/10.1007/ s10457-005-1090-8

EAFF (2012). East Africa Livestock Strategy. Nairobi: East Africa Farmers Federation.

FAO (2010). The Status of Conservation Agriculture in Southern Africa: Challenges and Opportunities for Expansion. REOSA Tech. Brief 03. Available at http://www.fao.org/ag/ca/doc/FAO_REOSA_Technical_Brief3.pdf (accessed 20 February 2018)

Fenta A.A., Hiroshi Y., Katsuyuki S., Nigussie H., Takayuki K., Dagnenet S., Kindiye E. and Sewale B.A. (2017). Spatial distribution and temporal trends of rainfall and erosivity in the Eastern Africa region. Hydrological Processes 31, 45554567. https://doi.org/10.1002/hyp.11378

Himmelstein J., Ares A., Gallagher D. and Myers J. (2017). A meta-analysis of intercropping in Africa: impacts on crop yield, farmer income, and integrated pest management effects. International Journal of Agricultural Sustainability 15, 1-10. https://doi.org/10.1080/14735903.2016.1242332

Ivask M., Kuu A., Truu M. and Truu J. (2006). The effect of soil type and soil moisture on earthworm communities. Agricultural Sciences 17, 7-11.

Jordán A., Zavala L.M. and Gil J. (2010). Effects of mulching on soil physical properties and runoff under semi-arid conditions in southern Spain. CATENA 81, 77-85. https://doi.org/10.1016/j.catena.2010.01.007 
Kaspar T.C., Singer J.W., Hatfield J.L. and Sauer T.J. (2011). The use of cover crops to manage soil. In ACSESS Publications, Soil Science Society of America. https://doi.org/10.2136/2011.soilmanagement.c21

Lin C., Tu S., Huang J. and Chen Y. (2009). The effect of plant hedgerows on the spatial distribution of soil erosion and soil fertility on sloping farmland in the purple-soil area of China. Soil \& Tillage Research 105, 307-312. https://doi.org/10.1016/ j.still.2009.01.001

Mongkhonsin B., Nakbanpote W., Meesungnoen O. and Prasad M.N.V. (2019). Chapter 4 - Adaptive and tolerance mechanisms in herbaceous plants exposed to cadmium. In Hasanuzzaman M., Prasad M.N.V. and Fujita M. (eds), Cadmium Toxicity and Tolerance in Plants. India: Academic Press, pp. 73-109.

Montgomery D.R. (2007). Soil erosion and agricultural sustainability. Proceedings of the National Academy of Sciences 104, 13268-13272. https://doi.org/10.1073/pnas.0611508104

Muoni T., Barnes A., Öborn I., Watson C.A., Bergkvist G., Shiluli M. and Duncan A. (2019). Farmer perceptions of legumes and their functions in smallholder farming systems in east Africa. International Journal of Agricultural Sustainability 17, 205-218. https://doi.org/10.1080/14735903.2019.1609166

Muoni T., Koomson E., Öborn I., Marohn C., Watson C.A., Bergkvist G., Barnes A., Cadisch G. and Duncan A. (2018). Effect of legume-crop mixtures on runoff and soil loss in Africa. Advances in Legume Science and Practice Conference. Aspects of Applied Biology 138, 43-47.

Mupangwa W. and Thierfelder C. (2014). Intensification of conservation agriculture systems for increased livestock feed and maize production in Zimbabwe. International Journal of Agricultural Sustainability 12, 425-439. https://doi.org/10.1080/ 14735903.2013.859836

Nyangena W. and Köhlin G. (2008). Estimating Returns to Soil and Water Conservation Investments: An Application to Crop Yield in Kenya. Discussion papers dp-08-32-efd, resources for the future. Available at www.efdinitiative.org/sites/ default/files/efd-dp-08-32.pdf (accessed 18 April 2018).

Okoba B.O. and Sterk G. (2010). Catchment-level evaluation of farmers' estimates of soil erosion and crop yield in the Central Highlands of Kenya. Land Degradation \& Development 21, 388-400. https://doi.org/10.1002/ldr.1003

Paterson D.G., Smith H.J. and van Greunen A. (2013). Evaluation of soil conservation measures on a highly erodible soil in the Free State province, South Africa. South African Journal of Plant and Soil 30, 213-217. https://doi.org/10.1080/ 02571862.2013.861029

Rapsomanikis G. (2015). The Economic Lives of Smallholder Farmers: An Analysis Based on Household Data from Nine Countries. Rome, Italy: FAO.

Salako F.K., Kirchhof G. and Tian G. (2006). Management of a previously eroded tropical Alfisol with herbaceous legumes: soil loss and physical properties under mound tillage. Soil \& Tillage Research 89, 185-195. https://doi.org/10.1016/j.still. 2005.07.010

Sigunga D. and Wandahwa P. (2015). Land and soil resources and their management for sustainable agricultural production in Kenya: current position and future challenges. Egerton Journal of Science and Technology 11, 66-86.

Thierfelder C. and Wall P.C. (2009). Effects of conservation agriculture techniques on infiltration and soil water content in Zambia and Zimbabwe. Soil \& Tillage Research 105, 217-227. https://doi.org/10.1016/j.still.2009.07.007

Verheijen F.G.A., Jones R.J.A., Rickson R.J. and Smith C.J. (2009). Tolerable versus actual soil erosion rates in Europe. Earth-Science Reviews 94, 23-38. https://doi.org/10.1016/j.earscirev.2009.02.003

Cite this article: Muoni T, Koomson E, Öborn I, Marohn C, Watson CA, Bergkvist G, Barnes A, Cadisch G, and Duncan A (2020). Reducing soil erosion in smallholder farming systems in east Africa through the introduction of different crop types. Experimental Agriculture 56, 183-195. https://doi.org/10.1017/S0014479719000280 